\title{
Case Report of Severe Lactic Acidosis and Persistent Diastolic Hypotension After Standard Dose Intermittent Salbutamol Nebulization in a Child: Rare Adverse Effects for Common Treatment.
}

\section{Marco Colombo ( $\nabla$ marco.colombo@asst-settelaghi.it )}

Ospedale Filippo Del Ponte Varese https://orcid.org/0000-0003-4947-519X

\section{Anna Plebani}

Pediatric Emergency Deparment: Filippo del Ponte Hospital, Varese

\section{Annalisa Bosco}

Department of Neonatology and Pediatrics, University of Insubria, Varese

Massimo Agosti

Department of Neonatology and Pediatrics, University of Insubria, Varese

\section{Case report}

Keywords: asthma exacerbations, salbutamol adverse drug reaction, lactic acidosis, diastolic hypotension

Posted Date: November 25th, 2020

DOI: https://doi.org/10.21203/rs.3.rs-113398/v1

License: (c) (1) This work is licensed under a Creative Commons Attribution 4.0 International License. Read Full License 


\section{Abstract}

\section{Background}

Salbutamol is a selective $\beta 2$ receptor agonist widely used to treat asthma and other conditions and it often represents the treatment of choice for reversing airflow obstruction both in emergency and domiciliary settings. However, it can be associated to a broad spectrum of side effects and even paradox effects, if administered intravenously, at high doses continuous nebulized treatment and even at standard doses intermittent nebulized treatment, the latter being the most hazardous due to its infrequency. Lactic acidosis and persistent diastolic hypotension secondary to intermittent salbutamol nebulization are rare in children, moreover at standard therapeutic doses during asthma exacerbations.

\section{Case presentation}

We present a case of a 12 year-old boy, $34 \mathrm{Kg}$, who experienced a serious drug reaction during a moderate asthma attack, after intermittent inhaled $(0.2 \mathrm{mg}$ in 3 hours interval - overall $1.4 \mathrm{mg}$ in 24 hours before arrival) and nebulized treatment ( $3.25 \mathrm{mg}$ in 20 minutes interval in 60 minutes, overall $11.25 \mathrm{mg}$ in our ED). He began experiencing symptoms of toxicity (tremor) in the emergency department few minutes after administration of the second dose of nebulized salbutamol, without reporting that to health care providers. Few minutes after the end of the third nebulized dose, clinical conditions worsened showing hyperglycemia (highest value $222 \mathrm{mg} / \mathrm{dl}$ ), hypokalemia (lowest value $2.6 \mathrm{mEq} / \mathrm{L}$ ), electrocardiogram alterations, decreased blood pressure (lowest value $87 / 33 \mathrm{~mm} / \mathrm{Hg}$ ), increased lactate serum level (highest value $8.1 \mathrm{mmol} / \mathrm{L}$ ). The patient fully recovered after discontinuation of salbutamol and was discharged after 24 hours of staying in the intensive brief observation unit of our pediatric emergency department.

\section{Conclusions}

We reinforce the message that not only intravenous administration or continuous nebulization of salbutamol can lead to severe complication in children, but also intermittent therapy given at standard doses. Then, health care providers should pay attention not only in emergency settings in order to achieve prompt recognition and proper management of this adverse reaction.

\section{Background}

Asthma exacerbation is one of the most common reasons for pediatric emergency department (PED) consultation and hospitalization [1]. Salbutamol is the medication of choice in Italy to treat asthma exacerbation due to its efficacy and deemed safety. However, reports of adverse cardiovascular and metabolic drug reactions (ADR) to salbutamol are increasing. Prompt recognition of these side effects is desirable for pediatricians in order to prevent bad outcomes and inapropriate treatment. 
Herein we describe a serious drug reaction to a standard dose of intermittent nebulized salbutamol in 12 year-old boy, that required prolonged staying in intensive brief observation unit of our PED.

\section{Case Presentation}

A 12 year old boy, $34 \mathrm{Kg}$, was referred to the PED with complaint of 24 hours lasting intermittent chest pain, cough, wheezing and mild fever. His ongoing medications consisted of $200 \mathrm{mcg}$ of inhaled salbutamol every 3 hours initiated the previous day, without medical advice (overall 1,4 mg/24 hours). Last administration had been performed one hour before arrival.

His medical history shown frequent episodes of vasovagal syncope triggered by blood samples collection, dust mites allergic asthma and exercise-induced asthma. Noteworthy, montelukast treatment was discontinued five days before the onset of symptoms on the advice of his pneumologist, after a three month-long period without asthma exacerbations. No prior exercise was reported and hypoallergenic material were correctly used in his bedroom night-time.

At presentation, vital signs were as follows: heart rate 110 beats per minute, respiratory rate 28 acts per minute, oxygen saturation in room air $94 \%$, temperature $37.1^{\circ} \mathrm{C}$ (Table 1 ).

Physical examination shown intercostal and substernal retractions, diffuse normal breath sound reduction with end-expiratory wheezing. His ability to speak was not affected. A pediatric asthma score of 9 was then calculated [2]. Capillary blood gas test at presentation is displayed in Table 2 as well as blood exams. It should be noticed that the patient reported dizziness, shortness of breath, and sensation of imminent loss of consciousness for few seconds following venous sampling and looked pale and sweaty at physical examination for few minutes. Consequently a 12-lead ECG was obtained showing sinus tachycardia. Blood pressure resulted normal at that time.

The patient was diagnosed with moderate asthma attack and was therefore treated with nebulized salbutamol $3.75 \mathrm{mg}(0.11 \mathrm{mg} / \mathrm{Kg})$ and ipratropium bromide $0.5 \mathrm{mg}$ at 20 minutes interval in the first hour and $40 \mathrm{mg}$ IV methylprednisolone.

Five minutes after the end of third nebulization, a second presyncope episode occurred. At the onset, his vital signs were normal, apart tachycardia (Table 1); at physical examination he shown tremor in his hands and looked pale, eupneic, with normal breath sounds and weak radial pulse. A 12-lead ECG was obtained (aspecific alteration of ventricular repolarization, QTc interval $467 \mathrm{msec}$ ), together with blood samples, showing normal troponin-T serum level. A normal saline infusion was therefore administred at $100 \mathrm{ml} / \mathrm{h}$ speed rate. At that moment the boy informed us he had noticed a transient and self-limited slight tremor in his hands since the end of the second nebulization, but neglected to mention.

Clinical conditions swiftly worsened in the following 30 minutes as the patient suffered faintness, extreme pallor, cold extremities with reduced normal breath sounds in lower-right lung quadrant. His vital signs shown $84 \%$ oxygen saturation in room air, blood hypotension $(90 / 40 \mathrm{mmHg})$ and tachycardia 
(140 bpm). A capillary blood gas test was obtained, showing metabolic acidosis with increased level of lactate, hypokalemia and hyperglycemia (Table 2), consequently two $500 \mathrm{ml}$ boluses of Ringer acetate were administered in 20 minutes each, because of persistent lower systolic and diastolic blood pressure (DBP); hypokalemia was treated with $500 \mathrm{ml}$ normal saline and $40 \mathrm{mEq} / \mathrm{L}$ of potassium chloride at $70 \mathrm{ml} / \mathrm{h}$ rate infusion in 3 hours; oxygen supplementation was started with Venturi mask providing a maximum $\mathrm{FiO}_{2}$ of 0.3 ; a chest $\mathrm{X}$-ray shown a small dystelectasis in right basis.

The patient was subsequently admitted to our intensive brief observation unit. Hypokalemia quickly reverted whereas lactic acidosis (highest value $8.1 \mathrm{mmol} / \mathrm{L}$ ) and lower DBP persisted for longer time (lowest value $33 \mathrm{mmHg}$ ). Oxygen supplementation was discontinued during night time, diuresis has always been normal, mainteinance normal saline infusion was continued till discharge.

Twenty-four hours later another 12-lead ECG was performed and a cardiologist consultancy excluded cardiovascular complications. The patient was eventually discharged with oral betametasone $1 \mathrm{mg} / \mathrm{Kg}$ for three days, nebulized ipratropium bromide $500 \mathrm{mcg}$ four times a day, montelukast $5 \mathrm{mg}$ a day.

One week later we performed a drug challenge test with $3 \mathrm{mg}$ of nebulized salbutamol resulting in no metabolic alterations nor hypotension.

\section{Discussion}

This case describes a serious ADR to salbutamol, as it caused a prolongation of existing hospitalization [3]. Salbutamol is the medication of choice in Italy to treat asthma exacerbations in children. Despite its deemed safety, reports of ADR are increasing in recent times, accounting for 1310 reports in 10 years from 2006 to 2016 from the European Medicines Agency, EudraVigilance database [4]. Moreover, a ADR is reported in $34,6-52 \%$ of intermittent salbutamol/albuterol administrations in children, according to Leung et al. [5].

Despite its recognized and well known $\beta 2$ airway receptors selectivity [6], salbutamol also exhibits $\beta 1$ activities, especially at higher doses [7], and $\beta 3$ activities [8] which can lead to a broad spectrum of side effects. Common side effects include tremor [9], dizziness, headache, reduced DBP, elevated troponin serum level, hyperglycemia, hypokalemia, lactic acidosis, acute urinary retention [8]. Severe side effects are more common after intravenous administration [10], oral [11], or high dose continuous nebulized therapy [5].

Lactic acidosis is a common finding in asthma, hypothetically due to inadequate oxygen delivery to the respiratory muscles [12]. Hypoxemia alone may lead "type A" lactic acidosis, which can occur also in poor tissue perfusion or shock. On the other hand, Salbutamol is one of the most reported drug involved in medications induced lactic acidosis [13] throughout the stimulation of the $\beta 2$-adrenergic receptor, which generates aerobic glycolysis leading to hyperglycemia [14] and high tissue pyruvate concentrations, eventually converted to lactate by lactate dehydrogenase ("type B2" lactid acidosis). Both these factors might have generated lactic acidosis in our patient. In the past, increased lactate to pyruvate 
concentrations ratio in the blood has been deemed to be a useful tool to distinguish type A and $B$ lactic acidosis [10], however its actual utility is controversial [15].

Diastolic hypotension is due to relaxation of vascular smooth muscle that might limit miocardial blood flow. Sarnaik et al [16] demonstrated a dose-dependent effect of high-dose continuos inhaled albuterol on DBP in two cohorts of children with status asmaticus during transport to the hospital or PICU admission (respectively $56 \%$ and $98 \%$ of children had at least one episode of low DBP). Hartford CT [17] found elevated troponin-T levels in $25 \%$ of children receiving at least $20 \mathrm{mcg} / \mathrm{hr}$ continous nebulized albuterol for a median duration of 40 hours. Carrol et al [18] noticed lower DBP in $66 \%$ of children who received 10 to $15 \mathrm{mg}$ /hour continuous albuterol for $>2$ hours. In addition $15 \%$ of the patients were found to have ECG ST-segment change and $24 \%$ had increased troponin-T serum levels. Finally Wisecup S et al. [19] found that lower DBP developed in $90 \%$ of children receiving a median weight-based dose continous nebulized albuterol of $12.7 \mathrm{mg} / \mathrm{Kg}$ for status asthmaticus with a positive correlation with increasing doses.

However, reports of severe ADR secondary to intermittent salbutamol nebulization are scarce in children. In 2015, Saadia and coworkers [20] first described 13-year- old female with intermittent asthma who developed lactic acidosis and diastolic hypotension after receiving $22.5 \mathrm{mg}$ of albuterol intermittent nebulizer treatment, that reverted after drug discontinuation and represented with drug readministration.

Interestingly our patient experienced also hyperglycemia, tremor and hypokalemia despite a lower dose, in addition we couldn't report any side effects after readministration and lactate to pyruvate blood ratio hasn't been performed because not available at our ED. Moreover, first capillary blood gas analysis shown slight increase of lactate and higher level of hemoglobin, suggesting a possible underlying hypovolaemia.

Given this, the diagnosis of salbutamol adverse drug reaction may be questionable in our patient, however, dehydration alone cannot explain the contemporary presence of hypokalemia, hypeglycemia, and persistent low diastolic pressure despite fluid infusion. Furthermore, no clinical sign of dehydration was present at physical examination. Hence we considered the diagnosis of dehydration unlikely.

Finally, we applied the "Naranjo's ADR correlation scale" obtaining a score of 6, meaning "probable correlation" [21]. Additionally, we ruled out other possible causes, such as adverse reaction to other medications and infections (negative reactive C-protein, self-limited fever). Questions may rise about fever, however Ylmaz et al. [22] first described a child who experienced fever as a side effect after salbutamol ingestion.

Even if a recent large meta-analysis about selective ß2-Adrenoceptor agonists induced lactic acidosis suggests that lactic acidosis is revertible even in patients who continued the drug[15], witholding salbutamol, possibly using an equally effective alternate drug to treat underlying condition, is pivotal if it will not affect the acute care of the patient. Given this, the management of this kind of ADR is purely symptomatic. Hypokalemia should be corrected carefully with frequent assessment of potassium serum levels. It has been suggested that administration of fluid boluses, before continuous nebulized albuterol, might prevent diastolic hypotension [19], however, to the best of our knowledge, evidence of the efficacy 
of such strategy before intermittent nebulized salbutamol are lacking in children. Fluid bolus administration is a possible option for management of salbutamol induced hypotension, but it may be counter-productive given the increased antidiuretic hormone secretion during acute asthma [23] and the peripheral vasodilation induced by salbutamol, potentially leading to fluid overload.

\section{Conclusions}

In conclusion, to the best of our knowledge, we described a severe adverse drug reactions after the lowest dosage ever reported of intermittent nebulized salbutamol. Clinicians should pay attention to otherwise unexplained lactic acydosis and/or persistent lower diastolic blood pressure while treating asthma exacerbations in children, even at standard doses of intermittent nebulized salbutamol, in order to prevent poor outcome and inappropriate management.

\section{Abbreviations}

pediatric emergency department, PED; adverse drug reaction, ADR; blood diastolic pressure, BDP; pediatric intensive care unit, PICU.

\section{Declarations}

\section{Ethics approval and consent to participate:}

Not applicable.

\section{Consent for publication:}

the patient's parents signed a written consent for publication.

\section{Availability of data and materials:}

The dataset supporting the conclusions of this article is included within the article

\section{Competing interests:}

The authors declare that they have no competing interests

\section{Authors' contributions:}

MC conceptualized and designed the study, reviewed the literature, collected and processed the data, and draft the manuscript. AB reviewed the literature and cowrote the clinical case. AP and MA reviewed the manuscript for important intellectual content. The author(s) read and approved the final manuscript.

\section{Funding:}


No funding was secured for this study

\section{Acknowledgements:}

not applicable.

\section{References}

1. Indinnimeo, L., Chiappini, E., Miraglia Del Giudice, M. Italian Panel for the management of acute asthma attack in children. Guideline on management of the acute asthma attack in children by Italian Society of Pediatrics. Ital J Pediatr. 2018;44(1):46. doi:10.1186/s13052-018-0481-1.

2. Kelly, C.S., Andersen, C.L., Pestian, J.P., et al. Improved outcomes for hospitalized asthmatic children using a clinical pathway. Ann Allergy Asthma Immunol. 2000;84(5):509 516. doi:10.1016/S10811206(10)62514-8.

3. Agaard, and Holme, H.E.; Paediatric adverse drug reactions following use of asthma medications in Europe from 2007 to 2011. Int J Clin Pharm 2014;36:1222-1229. doi 10.1007/s11096-014-0020-0.

4. Milano, G., Chiappini, S., Mattioli, F., Martelli, A. and Schifano, F. $\beta 2$ Agonists as Misusing Drugs? Assessment of both Clenbuterol and Salbutamol related European Medicines Agency Pharmacovigilance Database Reports. Basic Clin Pharmacol Toxicol. 2018;123:182-187. doi:10.1111/bcpt.12991.

5. Leung JS, Johnson DW, Sperou AJ, Crotts J, Saude E, Hartling L, et al. A systematic review of adverse drug events associated with administration of common asthma medications in children. PLoSONE 2017;12(8):e0182738. https://doi.org/10.1371/journal.pone.0182738

6. Johnson, M., The beta adreno receptor. Am J Respir Crit Care Med. 1998(158):s146-e156. doi.org/10.1164/ajrccm.158.supplement_2.13tac110.

7. Phillips, P.J., Vedig, A.E., Jones, P.L., et al. Metabolic and cardiovascular side effects of the beta 2adrenoceptor agonists salbutamol and Br J Clin Pharmacol. 1980;9:483-91. doi: 10.1111/j.13652125.1980.tb05844.x.

8. D'Auria, E., Mandelli, M., Di Dio, F., Riva, E. Urine retention in a child treated with oral salbutamol. Indian J 2012;44(4):518-19. doi: 10.4103/0253-7613.99338.

9. Nizet, T.A.C., Broeders, M.E.A.C., Folgering, H.Th.M. Tremor side effects of salbutamol, quantified by a laser pointer technique Resp Med. 2004;9(98):844-850. doi:10.1016/j.rmed.2004.02.024.

10. Habashy, D., Lam, T.L., Browne, G.J. The administration of b2-agonists for paediatric asthma and its adverse reaction in Australian and New Zealand emergency departments: a cross-sectional survey Eur J Emerg Med. 2003;10:219-224. doi: 1097/00063110-200309000-00012.

11. Shurman, , Passero, M.A. Unusual Vascular Reactions to Albuterol. Arch Intern Med. 1984;144:17711772. doi:10.1001/archinte.1984.00350210083015

12. Meert, K.L., McCaulley, L., Sarnaik, A.P. Mechanism of lactic acidosis in children with acute severe asthma. Pediatr Crit Care Med 2012;(1)13:28-31. doi: 1097/PCC.0b013e3182196aa2. 
13. Smith, Z.R., Horng, M., Rech, M.A. Medication-Induced Hyperlactatemia and Lactic Acidosis: A Systematic Review of the Literature. Pharmacotherapy 2019;39(9):946 963. doi:10.1002/phar.2316.

14. Dawson, K.P., Penna, A.C., Manglick, P. Acute asthma, salbutamol and hyperglycaemia. Acta Paediatr. 1995;84(3):305 307. doi:10.1111/j.1651-2227.1995.tb13633.x.

15. Liedtke AG, Lava SAG, Milani GP, et al. Selective ß2-Adrenoceptor Agonists and Relevant Hyperlactatemia: Systematic Review and Meta-Analysis. J Clin Med. 2019;9(1):71. doi:10.3390/jcm9010071

16. Sarnaik, S.M., Saladino, R.A., Manole, M. Diastolic hypotension is an unrecognized risk factor for $\beta$ agonist-associated myocardial injury in children with asthma. Pediatr Crit Care Med. 2013;14(6):e273-9. doi:10.1097/PCC.0b013e31828a7677.

17. Fagbuyi, D.B., Venkataraman, S., Carter, J.R., et al. Diastolic Hypotension, Troponin Elevation, and Electrocardiographic Changes Associated With the Management of Moderate to Severe Asthma in Children. Acad Emerg Med. 2016;23:816-822. doi: 1111/acem.12997

18. Carroll, C.L., Coro, M., Cowl, A., et al. Transient occult cardiotoxicity in children receivingcontinuous beta-agonist therapy. World J Pediatr 2014;10:324-329. doi.org/10.1007/s12519-014- 0467-z.

19. Wisecup, S., Eades, S., Hashmi, S.S., et al. Diastolic hypotension in pediatric patients with asthma receiving continuous albuterol. J asthma 2015;(52)7:693-698. doi:10.3109/02770903.2014.1002566.

20. Saadia, A.T., George, M., Haesoon, Lactic acidosis and diastolic hypotension after intermittent albuterol nebulization in a pediatric patient. Resp Med Case Reports. 2015(16):89e91. doi.org/10.1016/j.rmcr.2015.08.005.

21. Naranjo, C.A., Busto, U., Sellers, E.M., et al. A method for estimating the probability of adverse drug reactions. Clin Pharmacol Ther. 1981(30):239-245. doi:10.1038/clpt.1981.154.

22. Yilmaz, A.P.A., Kucukosmanoglu, H.L., Hennes, H. Salbutamol intoxication: is salbutamol a druginducing fever? a case report and treatment strategy. Eur J Emerg Med 2002;(9)2:179-182. doi: 10.1097/00063110-200206000-00016.

23. Dawson, P., Ferguson, D.M., West, J., et al. Acute asthma and antidiuretic hormone secretion. Thorax. 1983;38:589-591. doi: 10.1136/thx.38.8.589.

\section{Tables}


Table 1

Vital signs

\begin{tabular}{|c|c|c|c|c|c|c|}
\hline Time & $\begin{array}{l}\text { RR } \\
\text { (apm) }\end{array}$ & $\begin{array}{l}\text { Oxygen } \\
\text { Saturation }\end{array}$ & $\begin{array}{l}\text { HR } \\
(\mathrm{bpm})\end{array}$ & $\begin{array}{l}\text { BP } \\
(\mathrm{mmHg})\end{array}$ & $\begin{array}{l}\text { Tempreature } \\
\left({ }^{\circ} \mathrm{C}\right)\end{array}$ & Event \\
\hline $\begin{array}{l}9: 30 \\
\text { AM }\end{array}$ & 28 & $94 \%$ RA & 102 & NA & 37.1 & Arrival \\
\hline $\begin{array}{l}9: 50 \\
\text { AM }\end{array}$ & 30 & $93 \%$ RA & 140 & $110 / 75$ & NA & First presyncope episode \\
\hline $\begin{array}{l}10: 45 \\
\text { AM }\end{array}$ & 30 & $94 \% \mathrm{RA}$ & 110 & NA & NA & Before 2nd nebulization \\
\hline $\begin{array}{l}11: 05 \\
\text { AM }\end{array}$ & 28 & $98 \% \mathrm{RA}$ & 130 & NA & NA & Before 3rd nebulization \\
\hline \multirow[t]{2}{*}{$\begin{array}{l}11: 50 \\
\text { AM }\end{array}$} & 28 & $98 \% \mathrm{RA}$ & 110 & $100 / 80$ & NA & $\begin{array}{l}\text { Second presyncope } \\
\text { episode. Salbutamol }\end{array}$ \\
\hline & & & & & & discontinued \\
\hline $\begin{array}{l}\text { 12:15 } \\
\text { PM }\end{array}$ & 30 & $84 \% \mathrm{RA}$ & 140 & $90 / 40$ & NA & \\
\hline $\begin{array}{l}12: 55 \\
\text { PM }\end{array}$ & 24 & $\begin{array}{l}100 \% \mathrm{FiO}_{2} \\
0,4\end{array}$ & 125 & $87 / 33$ & NA & $\begin{array}{l}\text { After two Ringer Acetate } \\
\text { boluses }\end{array}$ \\
\hline $\begin{array}{l}1: 15 \\
\text { PM }\end{array}$ & 31 & $97 \% \mathrm{FiO}_{2} 0,3$ & 132 & $91 / 41$ & NA & \\
\hline $\begin{array}{l}2: 15 \\
\text { PM }\end{array}$ & 29 & $97 \% \mathrm{FiO}_{2} 0,3$ & 140 & $129 / 41$ & 37.8 & \\
\hline $\begin{array}{l}\text { 3:15 } \\
\text { PM }\end{array}$ & 30 & $98 \% \mathrm{FiO}_{2} 0,3$ & 150 & $110 / 49$ & 37.9 & \\
\hline $\begin{array}{l}4: 15 \\
\text { PM }\end{array}$ & NA & $98 \% \mathrm{FiO}_{2} 0,3$ & 140 & $100 / 40$ & NA & \\
\hline $\begin{array}{l}11: 00 \\
\text { PM }\end{array}$ & 28 & $98 \% \mathrm{RA}$ & 113 & $103 / 45$ & 37.7 & \\
\hline $\begin{array}{l}3: 00 \\
\text { AM }\end{array}$ & NA & $97 \%$ RA & 100 & $104 / 55$ & 36.5 & \\
\hline $\begin{array}{l}\text { 7:00 } \\
\text { AM }\end{array}$ & 26 & $97 \%$ RA & 100 & $95 / 50$ & 37.3 & \\
\hline $\begin{array}{l}10: 30 \\
\text { AM }\end{array}$ & 22 & $98 \% \mathrm{RA}$ & 87 & $109 / 59$ & NA & \\
\hline $\begin{array}{l}\text { 1:00 } \\
\text { PM }\end{array}$ & 28 & $97 \%$ RA & 96 & $116 / 72$ & 36.8 & Discharge \\
\hline
\end{tabular}




\begin{tabular}{|llllll|}
\hline Time & $\begin{array}{l}\text { RR } \\
(\mathrm{apm})\end{array}$ & $\begin{array}{l}\text { Oxygen } \\
\text { Saturation }\end{array}$ & $\begin{array}{l}\text { HR } \\
(\mathrm{bpm})\end{array}$ & $\begin{array}{l}\text { BP } \\
(\mathrm{mmHg})\end{array}$ & $\begin{array}{l}\text { Tempreature } \\
\left({ }^{\circ} \mathrm{C}\right)\end{array}$ \\
\hline NA, not available; & $\mathrm{RR}$, respiratory rate; apm, acts per minute; $\mathrm{RA}$, room air; $\mathrm{FiO}_{2}$ fraction of inspired \\
oxygen; & $\mathrm{HR}$, heart rate; bpm, beats per minute; ${ }^{\circ} \mathrm{C}$, degrees Celsius. \\
\hline
\end{tabular}


Table 2

Laboratory findings

\begin{tabular}{|c|c|c|c|c|c|c|c|}
\hline & \multirow{2}{*}{$\begin{array}{l}9: 30 \\
\text { AM } \\
\text { Arrival }\end{array}$} & $12: 00 \mathrm{AM}$ & \multirow{2}{*}{$\begin{array}{l}1: 30 \\
\text { PM }\end{array}$} & \multirow[t]{2}{*}{2 PM } & \multirow{2}{*}{$\begin{array}{l}\text { 3:30 } \\
\text { PM }\end{array}$} & \multirow{2}{*}{$\begin{array}{l}\text { 7:00 } \\
\text { PM }\end{array}$} & \multirow{2}{*}{$\begin{array}{l}+24 \text { hours } \\
\text { Discharge }\end{array}$} \\
\hline & & $\begin{array}{l}\text { After2nd } \\
\text { presyncope }\end{array}$ & & & & & \\
\hline $\mathrm{pH}$ & $\begin{array}{l}7.41 \\
(c)\end{array}$ & 7.33 (v) & $\begin{array}{l}7.32 \\
\text { (v) }\end{array}$ & $\begin{array}{l}7.38 \\
(a)\end{array}$ & $\begin{array}{l}7.33 \\
\text { (a) }\end{array}$ & $\begin{array}{l}7.39 \\
\text { (a) }\end{array}$ & $7.44(v)$ \\
\hline $\mathrm{FiO}_{2}$ & $\begin{array}{l}\text { Room } \\
\text { air }\end{array}$ & Room air & $\begin{array}{l}\text { Room } \\
\text { air }\end{array}$ & $\begin{array}{l}0.3 \\
\text { Venturi }\end{array}$ & $\begin{array}{l}0.3 \\
\text { Venturi }\end{array}$ & $\begin{array}{l}\text { Room } \\
\text { air }\end{array}$ & Room air \\
\hline $\mathrm{pO}_{2}(\mathrm{mmHg})$ & 46 & 52 & 57 & 63 & 76 & 89 & 52 \\
\hline $\begin{array}{l}\mathrm{pCO}_{2} \\
(\mathrm{mmHg})\end{array}$ & 34 & 35 & 33 & 25 & 32 & 29 & 35 \\
\hline $\begin{array}{l}\mathrm{HCO3}^{-} \\
(\mathrm{mmol} / \mathrm{L})\end{array}$ & 21.6 & 18.8 & 17.4 & 15.2 & 16.9 & 17.9 & 24.2 \\
\hline $\mathrm{BE}(\mathrm{mmol} / \mathrm{L})$ & -2.3 & -6.2 & -7.7 & -8.3 & -8 & -5.7 & +0.4 \\
\hline $\begin{array}{l}\text { Lactate } \\
(\mathrm{mmol} / \mathrm{L})\end{array}$ & 3.9 & 5.3 & 5.3 & 8.1 & 4.6 & 2.3 & 0.7 \\
\hline $\begin{array}{l}\text { Glucose } \\
(\mathrm{mg} / \mathrm{dl})\end{array}$ & 103 & 213 & 218 & 222 & 166 & 123 & 90 \\
\hline $\mathrm{K}^{+}(\mathrm{mEq} / \mathrm{L})$ & 4.2 & 2.6 & 2.9 & & 3.6 & 4.1 & 3.5 \\
\hline $\mathrm{Na}^{+}(\mathrm{mEq} / \mathrm{L})$ & 141 & 141 & 141 & & 142 & 138 & 143 \\
\hline $\mathrm{Cl}^{-}(\mathrm{mEq} / \mathrm{L})$ & 105 & 109 & 112 & & 112 & 112 & 109 \\
\hline $\begin{array}{l}\text { Leukocyte } \\
10^{9} / \mathrm{L}\end{array}$ & 6.58 & & & & & & \\
\hline $\mathrm{Hb}(\mathrm{g} / \mathrm{dl})$ & 15.2 & 13 & 12.1 & 12.8 & 12.8 & 13.9 & 12.9 \\
\hline $\begin{array}{l}\text { Platelets } \\
\left(10^{9} / \mathrm{L}\right)\end{array}$ & 312 & & & & & & \\
\hline $\begin{array}{l}\text { Creatinine } \\
(\mathrm{mg} / \mathrm{dl})\end{array}$ & 0.65 & & & & & & \\
\hline $\begin{array}{l}\text { Nitrogen } \\
(\mathrm{mg} / \mathrm{dl})\end{array}$ & 35 & & & & & & \\
\hline $\mathrm{RCP}(\mathrm{mg} / \mathrm{dl})$ & 0.32 & & & & & & \\
\hline $\begin{array}{l}\text { Troponin-T } \\
\text { (ng/ml) }\end{array}$ & & & $<0.03$ & & & & \\
\hline
\end{tabular}




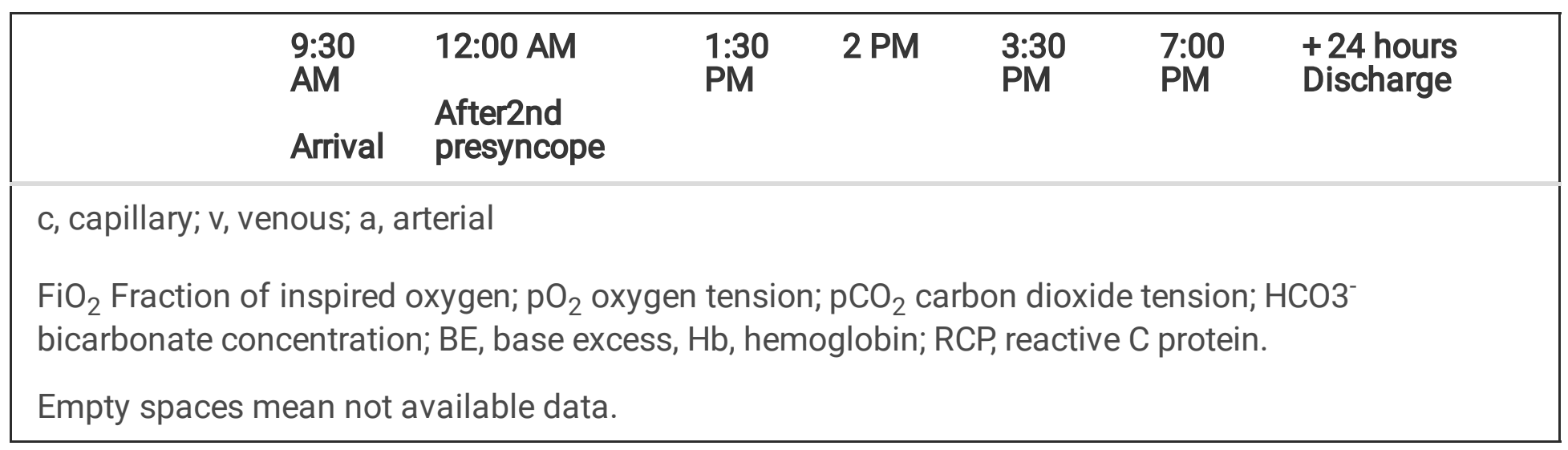

